\title{
PENGARUH RASIO KEUANGAN TERHADAP PERTUMBUHAN LABA PADA PERUSAHAAN ASURANSI YANG TERDAFTAR DI BURSA EFEK INDONESIA
}

\author{
Yuni Ajisti Herni \\ yuni.ajistih06@gmail.com \\ SEKOLAH TINGGI ILMU EKONOMI \\ “KEUANGAN, PERBANKAN DAN PEMBANGUNAN”, PADANG.
}

\begin{abstract}
This study aims to determine whether there is influence of financial ratios on profit growth. This research type is quantitative research that is data in the form of numbers and see influence between independent variable with dependent variable. The sample in this study amounted to ten Insurance Companies listed on the Indonesia Stock Exchange. The data analysis technique used is multiple linear regression using Eviews program. From the results of tests conducted show that: 1) Debt to Equity Ratio positive and no significant influence effect Profit growth, shown by probability $0.9306>0.05$ that is. 2) Return on Investments have positive and no significant effect on Profit growth, which is shown by probability $0.1476>0,05$ that is.
\end{abstract}

Keywords: Debt to Equity Ratio, Return on Investments, and Profit Growth

\section{PENDAHULUAN}

Seiring dengan laju tatanan perekonomian dunia yang telah mengalami perkembangan dan mengarah pada sistem ekonomi pasar bebas, perusahaanperusahaan semakin terdorong untuk meningkatkan daya saing. Suatu perusahaan dapat dikatakan mencapai kesuksesan dan berhasil memenangkan persaingan apabila dapat menghasilkan laba yang maksimal. Laba mencerminkan pengembalian kepada pemegang ekuitas untuk periode yang bersangkutan. Laba merupakan kenaikan manfaat ekonomi selama satu periode akuntansi dalam bentuk pemasukan atau penambahan aktiva atau penurunan kewajiban yang mengakibatkan kenaikan ekuitas yang tidak berasal dari kontribusi penanaman modal (Juliana dan Sulardi, 2003)

Tidak dapat dipungkiri bahwa pertumbuhan laba tidak bisa terlepas dari kinerja keuangan perusahaan. Salah satu alat analisis yang paling sering digunakan adalah rasio keuangan. Menurut Harahap (2006:297), rasio keuangan adalah angka yang diperoleh dari hasil perbandingan satu pos laporan keuangan dengan pos lainnya yang mempunyai hubungan yang relevan dan signifikan (Andriza \& Yusra, 2019; Putra \& Yusra, 2019; Suhartono \& Yusra, 2019; Yusra, Hadya, \& Fernandes, 2017). Menurut Kasmir (2009:104), rasio keuangan merupakan indeks yang menghubungkan dua angka akuntansi dan diperoleh dengan 
membagi satu angka dengan angka yang lainnya dalam satu periode maupun beberapa periode. Rasio keuangan dirancang untuk membantu dalam mengevaluasi suatu laporan keuangan (Brigham dan Hoston, 2006).

Hermanto

menyimpulkan bahwa rasio keuangan yaitu Debt to Equity Ratio berpengaruh positif dan signifikan terhadap pertumbuhan laba. Namun hasil penelitian tersebut berbeda dengan hasil penelitian Ismail (2010) yang menyatakan bahwa Debt Equity Ratio berpengaruh signifikan terhadap pertumbuhan laba. Sementara hasil penelitian Mardi,dkk (2012), yaitu untuk Return on Investmen berpengaruh positif dan signifikan terhadap pertumbuhan laba. Maka dari uraian diatas hipotesis yang dirumuskan dalam penelitian ini adalah:

$\mathrm{H} 1$ : Debt to equity ratio berpengaruh positif dan signifikan terhadap pertumbuhan laba.

$\mathrm{H} 2$ : Return on investment berpengaruh positif dan signifikan terhadap pertumbuhan laba.

Debt to Equity Ratio adalah rasio yang digunakan untuk menilai utang dengan ekuitas. Rasio ini berguna untuk mengetahui jumlah dana yang disediakan peminjam (kreditor) dengan pemilik perusahaan (Hanafi \& Yusra, 2019; Yusra et al., 2017), dimana Debt to Equity Ratio semakin besar maka akan baik bagi pertumbuhan pertumbuhan laba sebaliknya semakin rendah Debt to Equity Ratio maka semakin tinggi tingkat pendanaan yang disediakan pemilik dan semakin besar batas pengaman bagi peminjam jika terjadi kerugian atau penyusutan terhadap nilai aktiva dan akan berpengaruh terhadap pertumbuhan laba (Nurvigia, 2010). Rasio ini memberikan petunjuk umum tentang kelayakan dan risiko keuangan perusahaan. Rumus yang digunakan untuk menghitung rasio Debt to Equity Ratio ini adalah :

$$
\text { DER }=\frac{\text { Total hutang }}{\text { Equitas }} \times 100 \%
$$

Return on Investmen merupakan rasio yang menunjukan kemampuan perusahaan untuk menghasikan keuntungan yang akan digunakan untuk menutup investasi yang dikeluarkan dan juga merupakan ukuran efesiensi penggunaan modal didalam suatu perusahaan (Riyanto, 2001).

Rumus yang digunakan untuk menghitung rasio ini adalah:

$$
\mathrm{ROI}=\frac{\text { Laba bersih }}{\text { Total aktiva }} \times 100 \%
$$

Adapun rumusan masalah yang dapat dirumuskan pada penelitian ini adalah sebagai berikut: (a) Apakah Debt to Equity Ratio berpengaruh terhadap pertumbuhan laba pada perusahaan asuransi yang terdaftar di bursa efek indonesia? (b) Apakah Return on Investmen berpengaruh terhadap pertumbuhan laba pada perusahaan asuransi yang terdaftar di bursa efek Indonesia?

Sedangkan tujuan dari penelitian ini adalah sebagai berikut: (a) untuk menguji pengaruh Debt to Equity Ratio terhadap pertumbuhan laba pada perusahaan asuransi yang terdafrtar di bursa efek Indonesia? (b) untuk menguji pengaruh Return on Investmen terhadap pertumbuhan laba pada perusahaan asuransi yang terdaftar di bursa efek Indonesia? 


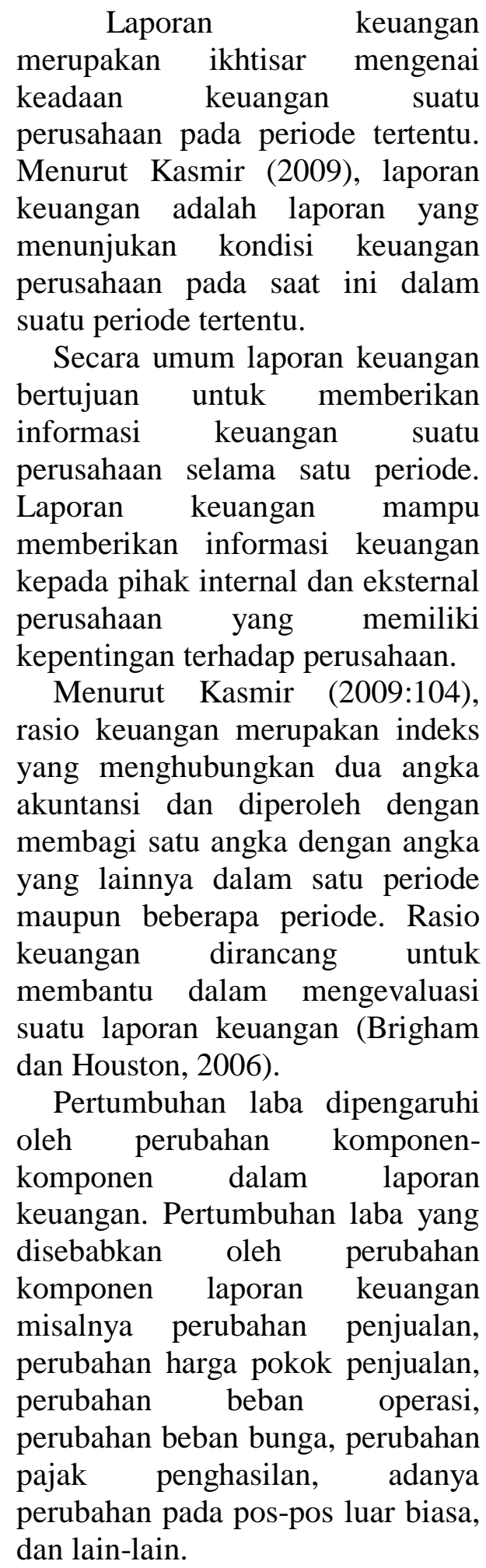

Menurut Warsidi dan Pramuka (2000:45) "Pertumbuhan laba dihitung dengan cara:

Laba bersih tahun $t-L a b a$ bersih tahun $t-1$ $\mathrm{x} 100 \%$
Laba bersih tahun $t-1$
Keterangan:

a. Laba bersih tahun t: laba bersih tahun berjalan

b. Laba bersih tahun-1: laba bersih tahun sebelumnya.

\section{METODE PENELITIAN}

Jenis penelitian yang ada dalam penelitian ini adalah penelitian kuantitatif. Pada jenis penelitian ini berbicara tentang angka-anga serta melihat pengaruh variabel independen dengan variabel dependen.

Populasi dalam penelitian ini adalah perusahaan asuransi yang terdaftar di Bursa Efek Indonesia. Sampel pada penelitian ini dipilih berdasarkan teknik pengambilan sampel purposive sampling dengan kriteria-kriteria tertentu yang telah dibuat oleh peneliti terhadap objek dalam penelitian ini adalah sebagai berikut: Perusahaan yang bergerak dalam bidang asuransi, perusahaan asuransi yang terdaftar di BEI tahun 2012-2016, laporan keuangan perusahaan periode 2012-2016 yang tersedia di BEI, perusahaan memperoleh laba pada tahun 2012-2016.

Penelitian ini menggunakan jenis data kuantitatif. Sumber data yang digunakan dalam penelitian ini adalah laporan keuangan perusahaan berupa neraca dan laporan laba rugi periode tahun 2012-2016, diakses melalui situs www.idx.co.id.

Teknik pengumpulan data yang dilakukan penulis menggunakan teknik studi pustaka seperti: jurnal-jurnal, 
buku, dan studi dokumenter seperti: laporan keuangan tahunan masing-masing perusahaan yang diperoleh dari website Bursa Efek Indonesia yaitu www.idx.co.id.

Pada penelitian ini menggunakan dua variabel yaitu : Variabel dependen, dalam penelitian ini adalah pertumbuhan laba (Y). Pertumbuhan laba berarti terjadi kenaikan atau penurunan dari aktiva dan kewajiban yang telah diolah dan berpengaruh terhadap modal perusahaan. Menurut Chairir dan Ghozali (2007), laba yang digunakan dalam penelitian ini adalah laba bersih. Menurut Warsidi dan Pramuka (2000:45) "Pertumbuhan laba dihitung dengan cara:

Laba bersih tahun $t$ - Laba bersih tahun $t-1$ $\mathrm{x} 100 \%$ Laba bersih tahun $t-1$

Keterangan: Laba bersih tahun $\mathrm{t}$ = laba bersih tahun berjalan, Laba bersih tahun $\mathrm{t}-1$ = laba bersih tahun sebelumnya.

Variabel independen, dalam penelitian ini adalah variabel Debt to Equity Ratio (DER) yang digunakan untuk menilai utang dengan ekuitas. Menurut Kasmir (2010:124) rumusan untuk mencari Debt to Equity Ratio dapat digunakan sebagai berikut: DER $=\frac{\text { Total hutang }}{\text { Equitas }} \times 100 \%$

Dan variabel Return On Investment (ROI) merupakan rasio yang menunjukan kemampuan perusahaan untuk menghasilkan keuntungan yang akan digunakan untuk menutup investasi yang dikeluarkan (Sutrisno. 2004). Rumus yang digunakan untuk menghitung rasio ini adalah:

$\mathrm{ROI}=\frac{\text { Laba bersih }}{\text { Total aktiva }} \times 100 \%$

Teknik analisis data dalam penelitian ini yaitu analisa statistik deskriptif. Pada uji statistik deskriptif ini berkenaan dengan bagaimana data dapat digambarkan/dideskripsikan, baik secara numerik misalnya menghitung rata-rata, standar deviasi atau secara grafis dalam bentuk tabel atau grafik.

Uji Asumsi klasik dalam penelitian ini: (a) Uji Normalitas, data terdistribusi normal dapat dilihat jika nilai Probabilty Jarque-Bera> tingkat alpha 5\% maka data terdistribusi secara normal, sebaliknya jika nilai Probability Jarque-Bera $<$ tingkat alpha 5\% maka data tidak terdistribusi secara normal.

Ho : Data yang tidak terdistribusi secara normal

$\mathrm{Ha}$ : Data yang terdistribusi secara normal

(b) Uji Multikolinearitas, Syarat tidak terjadi multikolinearitas adalah jika nilai korelasi antar variabel independen $<0,8$. Jika nilai korelasi > 0,8 maka terjadi multikolinearitas.(Gujarati,2003), (c) Uji Autokorelasi, uji yang digunakan untuk mendeteksi adanya gejala autokolerasi adalah Durbin-Waston Statistic Test. Jika Durbin-Wastonnya antara -2 sampai 2 berarti tidak terjadi autokorelasi (Gujarti, 2003), (d) Uji Heteroskesdastisitas, caranya dengan melihat white heterokedastisity test, dimana nilai probability $O b s * R$ squared $>\quad 0,05$ (alpha). Oleh karena itu nilai probability 
$O b s * R$-squared $>0,05$ maka tidak terjadi heterokesdastisitas.

Analisis Regresi Linear Berganda dalam penelitian ini dilakukan untuk mengetahui ada tidaknya pengaruh DER, ROI sebagai variabel bebas (independen variabel) terhadap pertumbuhan laba sebagai variabel terikat (dependen variabel).
Pembuktian hipotesis pada penelitian ini menggunakan model regresi linear berganda dengan tiga variabel bebas yaitu: $\mathrm{Y}=\mathrm{a}+\beta 1 \mathrm{X} 1+\beta 2 \mathrm{X} 2+\mathrm{e}$

Keterangan:

$\mathrm{Y}=$ pertumbuhan laba

$\mathrm{a}=$ konstanta

$\beta 1 \beta 2=$ koefisien regresi

$\mathrm{X} 1$ = variabel DER

$\mathrm{X} 2$ = variabel ROI

$\mathrm{e}=$ error term

HASIL DAN PEMBAHASAN

Uji Statistik Deskriptif Variabel Penelitian

Tabel.1

Deskriptif Statistik Variabel Penelitian

\begin{tabular}{llccll}
\hline \hline Variabel & N & Minimum & Maksimum & Mean & Standar Deviasi \\
\hline X1 & 37 & 0.203293 & 13.80488 & 2.130732 & 3.061589 \\
X2 & 37 & 0.018462 & 0.124002 & 0.067820 & 0.026035 \\
Y & 37 & 0.006965 & 11.95886 & 0.700147 & 1.973601 \\
\hline
\end{tabular}

Sumber: Data Diolah

Pada tabel 1 diatas menunjukkan bahwa jumlah data yang digunakan dalam penelitian ini adalah sebanyak 37 observasi yang diambil dari laporan tahunan perusahaan asuransi yang tercatat di BEI periode 2012-2016.

Data DER memiliki nilai terendah (minimum) sebesar $0.203293 \%$ dan nilai tertinggi (maksimum) sebesar $13.80488 \%$. Adapun nilai terendah tersebut terdapat pada perusahaan PNIN (Panin Insurance Tbk) pada tahun 2016. Sedangkan nilai tertinggi terdapat pada perusahaan ASJT (Asuransi Jaya Tania Tbk) pada tahun 2015. Kemudian rata-rata sebesar $2.130732 \%$ dengan nilai standar deviasi sebesar $3.061589 \%$ menunjukkan simpangan data relative besar, karena nilainya yang lebih besar daripada nilai mean-nya.
Data ROI mempunyai tingkat terendah (minimum) adalah $0.018462 \%$ dan nilai tertinggi ( maksimum) adalah $0.124002 \%$. Adapun data terendah tersebut terdapat pada perusahaan AHAP (Asuransi Harta Aman Pratama Tbk) tahun 2016. Sedangkan data tertinggi tersebut terdapat pada perusahaan MREI (Maskapai Reasuransi Indonesia Tbk) tahun 2012. kemudian rata-rata sebesar $0.067820 \%$ dengan nilai standar deviasi sebesar $0.026035 \%$ menunjukkan simpangan data relative kecil, karena nilainya yang lebih kecil daripada nilai mean-nya.

Data pertumbuhan laba mempunyai tingkat terendah (minimum) adalah $0.006965 \%$ dan nilai tertinggi ( maksimum) adalah $11.95886 \%$. Adapun data terendah tersebut terdapat pada perusahaan 
AHAP (Asuransi Harta Aman Pratama Tbk) tahun 2016. Sedangkan data tertinggi tersebut terdapat pada perusahaan ABDA (Asuransi Bina Dana Artha Tbk) tahun 2013. kemudian rata-rata sebesar $0.700147 \%$ dengan nilai standar deviasi sebesar $1.973601 \%$ menunjukkan simpangan data relative besar, karena nilainya yang lebih besar daripada nilai mean-nya.

\section{Uji Stasioneritas}

Table 2

Uji Stasioneritas variabel penelitian

\begin{tabular}{llll}
\hline \multirow{2}{*}{ Variabel } & \multicolumn{3}{c}{ Tingkat Stasioneritas } \\
\cline { 2 - 4 } & \multicolumn{3}{c}{ Level } \\
\cline { 2 - 4 } & t-statistic & Probability & Keterangan \\
\hline X1 & -5.346085 & 0.0001 & Stasioner \\
X2 & -3.598248 & 0.0107 & Stasioner \\
Y & $\mathbf{- 2 2 . 2 4 7 4 7}$ & 0.0001 & Stasioner \\
\hline \hline
\end{tabular}

Dilihat dari tabel 2 di atas perilaku data dari masing-masing variabel. berdasarkan hasil pengujian Augmented Dickey-Fuller (ADF) pada tingkat level yang mencangkup intercept, dapat dilihat bahwa pada variabel DER, ROI, dan pertumbuhan laba pada tingkat nilai absolut ADF nya lebih kecil dari nilai kritis dengan derajat keyakinan 0.05 .

\section{Uji Asumsi Klasik \\ Uji Normalitas}

Tabel 3

Hasil Uji Normalitas Data

\begin{tabular}{lcccc}
\hline \hline Variabel & $\mathrm{N}$ & Jarque-Bera & Probability & Keterangan \\
\hline $\mathrm{X} 1$ & 37 & 155.3237 & 0.000000 & Tidak Normal \\
$\mathrm{X} 2$ & 37 & 0.632253 & 0.728967 & Normal \\
$\mathrm{Y}$ & 37 & 1314.001 & 0.000000 & Tidak Normal \\
\hline \hline
\end{tabular}

Dilihat dari Tabel 3 diatas Probability untuk variabel DER sebesar 0.000000 berarti data tidak normal karena syarat untuk normal adalah probability jarque-bera > 0,05 , untuk variabel ROI sebesar 0.728967 berarti data normal, dan untuk variabel pertumbuhan laba sebesar 0.000000 berarti data tidak normal. Untuk menormalkan data pada variabel DER dan variabel pertumbuhan laba maka data asli ditransformasikan dengan menggunakan transformasi logaritma, transformasi ini dilakukan dengan rumus $=\mathrm{LN}(\mathrm{x})$, kemudian 
data dilakukan pengolahan kembali.

dilihat

di

bawah

ini.

Maka hasil dari pengolahan kembali

Tabel. 4

Hasil Uji Normalitas Diolah Kembali

\begin{tabular}{lllll}
\hline \hline Variabel & $\mathrm{N}$ & Jarque-Bera & Probability & Keterangan \\
\hline $\mathrm{X} 1$ & 37 & 1.159041 & 0.560167 & Normal \\
$\mathrm{X} 2$ & 37 & 0.632253 & 0.728967 & Normal \\
$\mathrm{Y}$ & 37 & 0.346917 & 0.840752 & Normal \\
\hline
\end{tabular}

Dari Tabel 4 diatas terlihat pada data Probability untuk variabel DER dan variabel pertumbuhan laba berarti data telah normal karena probability jarque-bera $>0,05$.

\section{Uji Multikolinearitas}

Tabel 5

Hasil Uji Multikolinearitas

\begin{tabular}{lcc}
\hline \hline & X1 & X2 \\
\hline X1 & 1 & -0.2994659608448603 \\
X2 & -0.2994659608448603 & 1 \\
\hline \hline
\end{tabular}

Berdasarkan hasil olahan data pada Tabel 5 terlihat nilai kolerasi antara sesama variabel independen <
0,8 sehingga dapat dikatakan bahwa sesama variabel independen tidak memilikihubungan multikolinearitas.

\section{Uji Autokorelasi}

Tabel 6

Hasil Uji Durbin -Watson

\begin{tabular}{lc}
\hline \hline Model & Durbin-watson \\
\hline 1 & 1.984996 \\
\hline
\end{tabular}

Dari uji Durbin-watson pada Tabel 6 terlihat bahwa tidak terjadi autokorelasi karena nilai DW antara $-2<1.984996<2$.

\section{Uji Heteroskedastisitas}

Tabel 7

Hasil Uji Heteroskedastisitas

\begin{tabular}{lccc}
\hline \hline F-statistic & 0.135172 & Probability & 0.8740 \\
\hline Obs*R-squared & 0.291877 & Probability & 0.8642 \\
\hline \hline
\end{tabular}




$\begin{array}{rrrrr}\text { Pada tabel } 7 \text { terlihat tidak } & \text { nilai } & \text { probability } & \text { Obs } * R \text {-squared } \\ \text { terjadi heterokesdastisitas karena } & \text { yaitu } & 0.8642 & > & 0,05 .\end{array}$

Tabel 8

Hasil Uji Regresi Linier Berganda

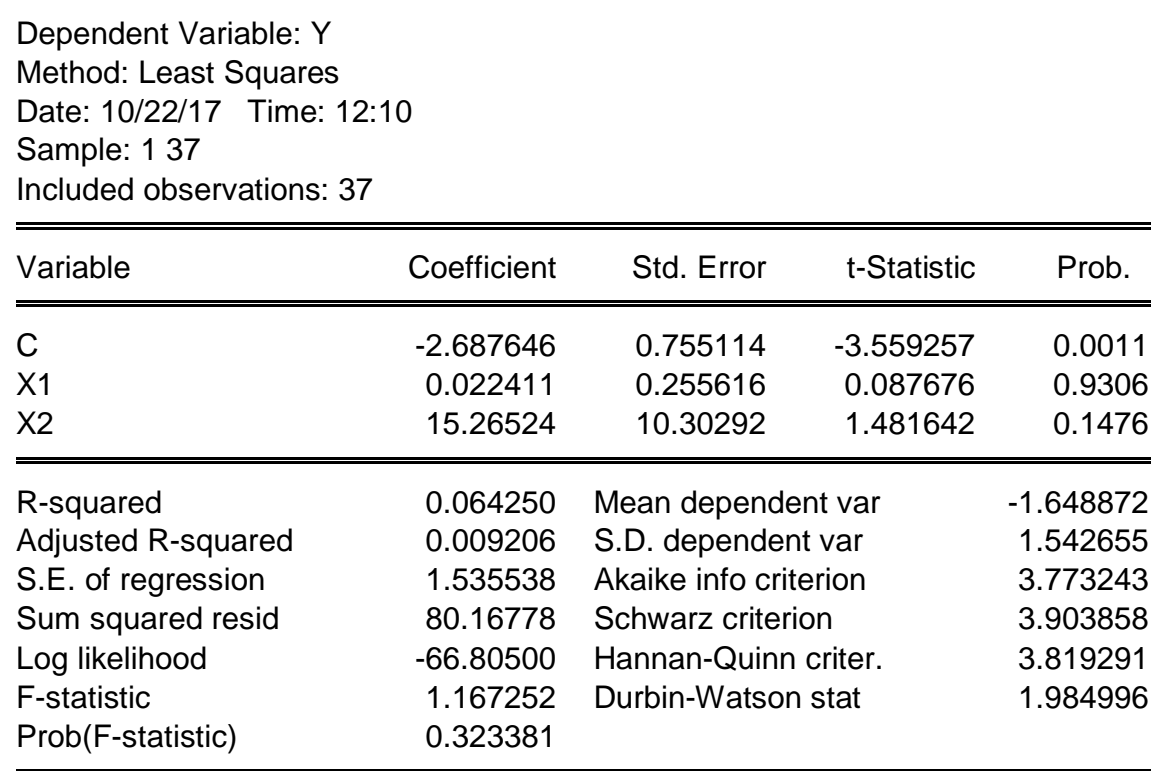

Dari tabel 8 diatas, dapat dituliskan persamaan sebagai berikut:

$$
\mathrm{Y}=-2.687646+0.022411 \mathrm{X} 1+
$$

$15.26524 \mathrm{X} 2+\mathrm{e}$.

Keterangan :

1. Konstanta -2.687646 sebesar dengan tanda negatif menunjukkan bahwa apabila variabel independen tetap maka pertumbuhan laba sebesar -2.687646 (tidak terjadi pertumbuhan laba).

2. Variabel Debt to Equity Ratio memiliki nilai koefisien regresi yang positif yaitu sebesar 0.022411. Hal ini menggambarkan bahwa nilai pertumbuhan laba akan mengalami peningkatan

\section{HIPOTESIS}

Dari Tabel 8 dihasilkan nilai $F$ Statistic sebesar 1.167252 dengan sebesar koefisien pengali dari DER, yaitu senilai 0.022411 bila DER mengalami kenaikan sebanyak 1 satuan dengan asumsi variabel independen lain konstan.

3. Variabel Return on Investmenmemiliki nilai koefisien regresi yang positif yaitu sebesar 15.26524. Hal ini menggambarkan bahwa nilai pertumbuhan laba akan mengalami peningkatan sebesar koefisien pengali dari ROI, yaitu senilai 15.26524 bila ROI mengalami kenaikan sebanyak 1 satuan dengan asumsi variabel independen lain

konstan.

\section{Uji f}

nilai signifikansi probability $F$ Statistic adalah 0.323381, tingkat 
probabilitasnya lebih besar dari 0,05 atau > 0,05. Hal tersebut mengidentifikasi bahwa variabel Uji t

Uji $\mathrm{t}$ digunakan untuk melihat besarnya pengaruh dari variabel bebas secara parsial terhadap variabel terikatnya. Untuk mengetahui pengaruh variabel bebas secara parsial terhadap variabel terikatnya maka hasil $t_{\text {hitung }}$ dibandingkan dengan tingkat $\alpha=0,05$. Jika $t_{\text {hitung }}<0,05$ maka Ho ditolak, berarti Ha diterima, dimana Debt to Equity Ratio berpengaruh positif dan signifikan terhadap perrtumbuhan laba. Dan pada variabel Return on Investmen Ho ditolak, Ha diterima, dimana Return on Investman berpengaruh positif dan signifikan terhadap pertumbuhan laba.

Dari hasil pengolahan data dihasilkan Debt to Equity Ratio menunjukkan thitung 0.087676 dengan nilai yang tidak signifikan 0.9306 besar dari tingkat alpha 0,05 dan koefisien $\beta$ sebesar 0.022411 menunjukkan nilai positif. Hal ini berarti bahwa Debt to Equity Ratio berpengaruh positif dan tidak signifikan terhadap pertumbuhan laba.

Return on Investmen menunjukan thitung 1.481642 dengan nilai yang tidak signifikan 0.1476 besar dari alpha 0,05 dan koefisien $\beta$ sebesar 15.26524 menunjukan positif. Hal ini berarti bahwa Return on Investmen berpengaruh positif dan tidak signifikan terhadap pertumbuhan laba.

\section{Koefisien Determinasi $\left(\boldsymbol{R}^{2}\right)$}

Adjusted $R$-squared digunakan untuk mengukur seberapa besar proporsi variasi dari variable independen secara bersama-sama dalam menjelaskan variable independen (DER dan ROI) berpengaruh secara signifikan terhadap variabel dependen.

dependen. Dari hasil pengolahan data ditemukan nilai Adjusted $R$-squared 0.009206 ini berarti bahwa variabel bebas DER (Debt to equity ratio) dan ROI (Return on investmen) mampu menjelaskan pertumbuhan laba sebesar 92,06\% sedangkan sisanya $7,94 \%$ dipengaruhi oleh faktor lain. Misalnya ROE, ROA.

\section{PEMBAHASAN}

\section{Pengaruh Debt to Equity Ratio Terhadap Pertumbuhan Laba}

Dari Tabel 8 dihasilkan nilai koefisien regresi untuk variabel Debt to Equity Ratio yang diproxy oleh pertumbuhan laba sebesar 0.022411 bertanda positif dengan nilai probability $0.9306>0.05$ yang berarti bahwa nilai Debt to Equity Ratio mempunyai pengaruh positif yang tidak signifikan terhadap pertumbuhan laba. Dengan demikian dapat disimpulkan hipotesis pertama diterima.

Pengaruh positif yang diberikan variabel Debt to Equity Ratio terhadap pertumbuhan laba menujukkan bahwa penguatan Debt to Equity Ratio justru akan meningkatkan pertumbuhan laba. Hasil penelitian ini sama dengan penelitian Ade Gunawan dan Sri Fitri Wahyuni menyimpulkan bahwa rasio keuangan yaitu Debt to Equity Ratio berpengaruh positif dan tidak signifikan terhadap pertumbuhan laba.

Penelitian ini mempunyai kesamaan hasil dengan penelitiannya yang dilakukan oleh Ismail (2010) menyatakan bahwa Debt to Equity Ratio berpengaruh positif dan tidak 
signifikan terhadap pertumbuhan laba.

Penelitian ini mempunyai hasil yang berbeda dengan penelitian yang dilakukan Oktanto dan Nuryatno (2014) yang menyatakan bahwa Debt Equity Ratio bepengaruh positif dan signifikan terhadap pertumbuhan laba.

\section{Pengaruh Return on Investmen} Terhadap Pertumbuhan Laba

Dari Tabel 8 dihasilkan nilai koefisien regresi untuk variabel Return on Investmenyang diproxy oleh pertumbuhan laba sebesar 15.26524 bertanda positif dengan nilai probability $0.1476>0.05$ yang berarti bahwa nilai Return on Investmen mempunyai pengaruh positif yang tidak signifikan terhadap pertumbuhan laba. Dengan demikian dapat disimpulkan hipotesis kedua diterima.

Hasil penelitian ini sama dengan penelitian Mardi,dkk (2012), yaitu untuk Return on Investmen berpengaruh positif dan tidak signifikan terhadap pertumbuhan laba. Penelitian ini mempunyai kesamaan hasil dengan penelitian yang dilakukan oleh Ayuning Untari Sitorus (2010) dalam penelitiannya menunjukan bahwa Return on Investmen berpengaruh positif dan tidak signifikan terhadap pertumbuhan laba.

Penelitian ini mempunyai hasil yang berbeda dengan penelitian yang dilakukan oleh Epri Ayu Hapsari (2007) dalam penelitiannya menunjukan bahwa Return on Investmen bepengaruh positif dan signifikan terhadap pertumbuhan laba.

\section{PENUTUP}

\section{Kesimpulan}

Berdasarkan hasil penelitian dan pembahasan mengenai pengaruh rasio keuangan terhadap pertumbuhan laba pada perusahaan asuransi di periode 2012-2016 dengan menggunakan teknik analisis regresi linier berganda maka diperoleh kesimpulan sebagai berikut:

1. Hasil uji $\mathrm{f}$ (simultan) menunjukkan bahwa variabel independen (DER,ROI) berpengaruh secara signifikan terhadap variabel dependen (pertumbuhan laba).

2. Uji t (parsial) menunjukkan bahwavariabel Debt to Equity Ratio berpengaruh positif yang tidak signifikan terhadap pertumbuhan laba, sedangkan variabel Return on Investmen berpengaruh positif yang tidak signifikan terhadap pertumbuhan laba.

3. Koefisien determinasi $\left(\mathrm{R}^{2}\right)$ yang digunakan dalam penelitian ini adalah Adjusted $R$-squared sebesar 0.009206 ini berarti bahwa variabel bebas DER (Debt to equity ratio) dan ROI (Return on investmen) mampu menjelaskan pertumbuhan laba sebesar $\quad 92,06 \%$ sedangkan sisanya $7,94 \%$ dipengaruhi oleh faktor lain. Misalnya ROE, ROA.

\section{Saran}

Bagi perusahaan, Untuk meningkatkan pendapatan supaya laba perusahaan juga meningkat. Peningkatan pendapatan bisa dilakukan dengan meningkatkan polis asuransi.

Bagi peneliti selanjutnya agar dapat memperpanjang periode 
pengamatan sehingga jumlah sampel penelitian juga lebih banyak sehingga dapat meningkatkan distribusi data yang lebih baik dan dan menyertakan variabel yang lain untuk melihat pengaruh signifikan terhadap pertumbuhan laba sehingga hasilnya lebih akurat dan mempunyai cakupan yang lebih luas.

\section{DAFTAR PUSTAKA}

Andriza, R., \& Yusra, I. (2019). Pengaruh kepemilikan manajerial dan kebijakan deviden terhadap kemakmuran Investor dan nilai perusahaan yang tercatat pada indeks LQ45. INA-Rxiv.

Brigham. Eugene F. dan Joel F. Houston, (2006), Dasar-Dasar Manajemen Keuangan, Buku Satu. Edisi Kesepuluh, Alih Bahasa Ali Akbar Yulianto, Jakarta: Salemba Empat.

Fuad dan Rustam, (2005), Dasardasar Manajemen Keuangan, Jakarta: Bumi Aksara.

Ghozali, Imam, (2005), Aplikasi Analisis Multivariate dengan Program SPSS, Badan Penerbit Universitas Diponegoro, Semarang.

http://Analisa.blogspot.com/2012/II/ pengertian-manfaat-dan-jenisasuransi.html diakses 30 oktober 2013

http://repository.uin-suska.acid/4051/

http://www.idx.co.id.

Hanafi, D., \& Yusra, I. (2019).

Tangibility, liquidity, growth opportunity, dan leverage: studi pada perusahaan terdaftar di
Bursa Efek Indonesia. INA-

Rxiv, (2001).

Hanafi, Mamduh M. dan Abdul Halim, (2008), Analisis Laporan Keuangan, Edisi Ketiga, Penerbit ISBN, Jakarta.

Hapsari, Epri Ayu, (2007), Analisis Rasio Keuangan untuk Memprediksi Pertumbuhan Laba pada Perusahaan Manufaktur yang Terdaftar Di Bursa Efek, Jakarta. Skipsi. Semarang: Universitas Diponogoro.

Harahap, Sofyan Syafari, (2006), Analisis Kritis Atas Laporan Keuangan, Edisi Pertama, Jakarta: PT. Raja Grafindo Persada.

Hermanto, Suwardi B, (2007), Pengaruh Sistem Informasi dan Rasio Keuangan terhadap Perubahan Laba, Skripsi Jurusan Akuntansi, Medan: Fakultas Ekonomi Universitas Sumatera Utara.

Ikatan Akuntansi Indonesia, Standar Akutansi Keuangan, Per 1 September 2007, Penerbit: Salemba Empat, Jakarta.

Juliana dan Sulardi, (2003), Manfaat Rasio Keuagan dalam Memprediksi Perubahan Laba pada Perusahaan Manufaktur, Jurnal Bisnis dan Manajemen, Vol.3, No.2: Hal.108126.

Kasmir, (2008), Analisis Laporan Keuangan, edisi pertama, cetakan Pertama, Penerbit: Rajawali Pers, Jakarta.

Kasmir, (2009), Analisis Laporan Keuangan, Penerbit Rajawali Pers, Jakarta. 
Kasmir, (2009), Analisis Laporan Keuangan, Jakarta.

Kieso, Weygandt, Warfield, (2007), "Akuntansi Intermediate" Edisi Kedua Belas, Penerbit : ERLANGGA, Jakarta.

Mardi dkk, (2012), Pengaruh Rasio Keuangan Terhadap Pertumbuhan Laba pada perusahaan asuransi yang terdaftar di Bursa Efek Indonesia tahun 2007-2011

Munawir, (2004), Analisis Laporan Keuangan, Yogyakarta: BPFE.

Priyatno, Duwi, (2012), Belajar Cepat Olah Data dengan SPSS, Yogyakarta: Andi.

Putra, I., \& Yusra, I. (2019). Analisis likuiditas saham menggunakan regresi data panel. INA-Rxiv.

Sitorus, Untari, Ayuning, (2010), "Pengaruh Rasio Keuangan Terhadap Pertumbuhan Laba pada Perusahaan Asuransi yang terdaftar di Bursa Efek Indonesia”, Fakultas Ekonomi Medan.

Soemarso, (2005), Akuntansi Suatu Pengantar, Edisi 5, Penerbit Salemba Empat, Jakarta.

Sugiyono, (2008), Metode Penelitian Administrasi Dilengkapi Dengan
Metode R\&D, (Edisi Revisi), Bandung: Alfabeta.

Suhartono, \& Yusra, I. (2019). Analisis perbandingan kinerja keuangan bank konvensional dengan bank syariah yang terdaftar di BEI. INA-Rxiv, 1-9.

Sutrisno, (2004), Manajemen Keuangan: Teori, Konsep, dan Aplikasi, Ekonisia, Yogyakarta.

Slamet, Achmad, (2003), Analisis Laporan Keuangan, Semarang: Ekonomi unnes.

Thaussie Nurvigia, (2010), "Pengaruh Rasio-Rasio Keuangan Terhadap Perubahan Laba pada Perusahaan Otomotif yang Terdaftar di BEI", Skripsi, Fakultas Ekonomi, Universitas Pembangunan Nasional "Veteran", Jakarta.

Warsidi, dan Bambang Agus Pramuka (2000), "Evaluasi Kegunaan Rasio Keuangan Dalam Memprediksi Perubahan Laba di Masa Yang Akan Datang", Jurnal akuntansi dan Ekonomi, Vol.2, No.1.

Yusra, I., Hadya, R., \& Fernandes, J. (2017). Likuiditas , financial leverage, dan prediktabilitas beta: pendekatan Fowler and Rorke sebagai metode koreksi Beta. Jurnal Benefita, 2(1), 8191. 